J. Clin. Chem. Clin. Biochem.

Vol. 23, 1985, pp. $805-810$

\title{
Comparison of Several Atherogenicity Indices by the Analysis of Serum Lipoprotein Composition in Patients with Chronic Renal Failure with or without Haemodialysis, and in Renal Transplant Patients
}

\author{
By B. Lacour, J.-B. Roullet, P. Beyne, H. Kreis, M. Thevenin and T. Drüeke
}

Laboratoire de Biochimie A, Département de Néphrologie and INSERM Unité 90, Hôpital Necker, Paris, France

(Received July 20, 1984/July 8, 1985)

Summary: We investigated serum lipoproteins in uraemic and kidney transplant patients, and compared the results with those from normal persons. In uraemic patients, with or. without haemodialysis, and in kidney transplant patients, the ratio of HDL-cholesterol to total cholesterol minus HDL-cholesterol, the ratio of HDL-phospholipids to total phospholipids minus HDL-phospholipids, and the ratio of apolipoprotein A to apolipoprotein B are all decreased, though to different extents, when compared with healthy control subjects. Furthermore, important differences exist in the relative HDL composition between the 3 patient groups and healthy control subjects. Thus, the ratio of apolipoprotein A/HDL-cholesterol and that of HDL-cholesterol/ HDL-phospholipids are significantly altered in uraemic haemodialyzed patients, while the ratio of apolipoprotein A/HDL-phospholipids is normal. By contrast, the 3 ratios are normal in uraemic undialyzed patients, and the 2 ratios, apolipoprotein A/HDL-cholesterol and apolipoprotein A/HDL-phospholipids are normal in renal transplant patients. The last ratio, HDL-cholesterol/HDL-phospholipids, is increased in this group of patients. Thus, it appears that HDL-cholesterol, HDL-phospholipids, and total apolipoprotein A represent different aspects of the same lipoprotein. The determination of all three parameters could lead to a different approach in the evaluation of the so-called cardiovascular risk, at least for uraemic patients and renal transplant patients.

Vergleich mehrerer Atherogenitätsanzeichen durch Analyse der Zusammensetzung der Lipoproteine im Serum von Patienten mit chronischem Nierenversagen mit oder ohne Hämodialyse und nach Nierentransplantation

Zusammenfassung: Wir untersuchten die Lipoproteine im Serum von Patienten mit Urämie und nach Nierentransplantation und verglichen die Ergebnisse mit denen Gesunder. Bei urämischen Patienten mit oder ohne Hämodialyse und nach Nierentransplantation waren die Quotienten HDL-Cholesterin/Gesamt- - HDLCholesterin, HDL-Phospholipide/Gesamt- - HDL-Phospholipide und Apolipoprotein A/Apolipoprotein B, verglichen mit gesunden Kontrollpersonen, alle erniedrigt, wenn auch in verschiedenem Ausmaß. Weiterhin bestehen bedeutende Unterschiede in der Zusammensetzung der HDL zwischen den drei Patientengruppen und den gesunden Kontrollpersonen. So sind die Quotienten Apolipoprotein A/HDL-Cholesterin und HDLCholesterin/HDL-Phospholipide bei urämischen, hämodialysierten Patienten signifikant verändert, während der Quotient Apolipoprotein A/HDL-Phospholipide normal ist. Dagegen sind bei urämischen, nicht-dialysierten Patienten die drei Quotienten normal und die zwei Quotienten Apolipoprotein A/HDL-Cholesterin und Apolipoprotein A/HDL-Phospholipide sind bei Patienten mit Nierentransplantation normal. Der dritte Quotient, HDL-Cholesterin/HDL-Phospholipide, ist bei diesen Patienten erhöht. Es scheint daher, daß HDLCholesterin, HDL-Phospholipide und Gesamt-Apolipoprotein A verschiedene Aspekte desselben Lipoproteins repräsentieren. Die Bestimmung aller drei Kenngrößen könnte zu einem unterschiedlichen Ansatz für die Bewertung des sogenannten kardiovaskulären Risikos, zumindest für urämische Patienten und Patienten nach Nierentransplantation, führen. 


\section{Introduction}

Atherosclerotic cardiovascular disease appears to be one of the major causes of premature death in patients with chronic renal failure and in renal transplant patients $(1-5)$. In both groups of patients, dyslipoproteinaemia is common (review in l. c. $(6,7)$ ).

In non-uraemic subjects, epidemiological studies have indicated that serum high-density lipoprotein cholesterol independently of other risk factors is the most powerful lipid predictor of coronary events $(8-10)$. It has also been reported that serum HDL phospholipids may have a major predictive value in the assessment of cardiovascular risk (11). Recently, it has been reported that patients with significant coronary artery disease are more accurately identified by serum apolipoprotein A - I than by HDL-cholesterol (12).

In uraemic patients on intermittent haemodialysis, serum HDL-cholesterol in usually decreased or in the low-normal range (6-7). However, Brunzell et. al. (13) have shown that various levels of serum HDLcholesterol could be found for a given level of serum apolipoprotein $\mathrm{A}-\mathrm{I}$. As to renal transplant recipients, Jung et al. (14) suggested that the changes in serum HDL composition often encountered in that setting should be taken into account when considering the pathogenesis of the high incidence of cardiovascular disease in these patients.

In most studies on patients with chronic renal failure treated by dialysis or transplantation, HDL have been determined in terms of their cholesterol content. Only a few studies have been reported with determinations of serum apolipoprotein A (13-20).

The purpose of the present study in uraemic as well as in kidney transplant patients was to compare the atherogenic risk factors expressed as the ratio of serum concentrations of apolipoprotein A to apolipoprotein $\mathrm{B}$; the ratio of serum HDL-cholesterol to total cholesterol minus HDL-cholesterol, i. e., the cholesterol contained in serum low density and very low density lipoproteins (LDL + VLDL); and the ratio of serum HDL-phospholipids to total phospholipids minus HDL-phospholipids.

\section{Patients and Methods}

Patients

Serum lipid concentrations were studied in 4 groups of subjects: a group of 82 healthy volunteers,

a group of 61 undialysed patients with chronic renal failure,

a group of 89 uraemic patients on intermittent haemodialysis, and

a group of 22 renal transplant patients (tab. 1).
Tab. 1. Number of subjects and mean age in each group studied.

\begin{tabular}{|c|c|c|c|c|c|}
\hline & \multicolumn{2}{|c|}{ Healthy controls } & \multirow[b]{2}{*}{$\begin{array}{l}\text { Uraemic } \\
\text { un- } \\
\text { dialysed } \\
\text { patients }\end{array}$} & \multirow[b]{2}{*}{$\begin{array}{l}\text { Uraemic } \\
\text { haemo- } \\
\text { dialysed } \\
\text { patients }\end{array}$} & \multirow[b]{2}{*}{$\begin{array}{l}\text { Renal } \\
\text { trans- } \\
\text { plant } \\
\text { patients }\end{array}$} \\
\hline & Total & $\begin{array}{l}\text { Subgroup } \\
\text { matched } \\
\text { for } \\
\text { uraemics }\end{array}$ & & & \\
\hline $\begin{array}{l}\text { No. of } \\
\text { men }\end{array}$ & 34 & 12 & 37 & $4 \overline{7}$ & 14 \\
\hline $\begin{array}{l}\text { No. of } \\
\text { women }\end{array}$ & 48 & 10 & 24 & 42 & 8 \\
\hline $\begin{array}{l}\text { Mean age } \\
\pm \text { SEM }\end{array}$ & $\begin{array}{l}34.1 \\
\pm 1.19\end{array}$ & $\begin{array}{l}48.5 \\
\pm 1.37\end{array}$ & $\begin{array}{l}55.1 \\
\pm 1.95\end{array}$ & $\begin{array}{l}50.2 \\
\pm 1.65\end{array}$ & $\begin{array}{l}32.7 \\
\pm 1.94\end{array}$ \\
\hline
\end{tabular}

Healthy subjects were a representative sample of the same population group. They were selected during the various population screens by one of us (T.D.) as subjects apparently in good health, excluding thyroid and hepatic diseases, diabetes mellitus, hypertension, and primary hyperlipoproteinaemia. None of the subjects were taking medications. Among the 82 subjects, a subgroup of 22 had a mean age similar to that of the uraemic patients studied.

Among the group of uraemic undialysed patients, the serum creatinine concentration was below $400 \mu \mathrm{mol} / 1$ in 26 patients and above that value in 35 . Haemodialysed patients had an average dialysis time of $46.4 \pm 4.6$ (SEM) months. The incidence of different types of nephropathies was similar in both latter groups. Renal transplant patients had been transplanted for more than 3 months and had a normal or near normal glomerular function as evidenced by a creatinine clearance $\geqq$ $1.33 \mathrm{ml} / \mathrm{s}$.

\section{Biochemical determinations}

For each subject, $10 \mathrm{ml}$ of venous blood were drawn after a $12-14 \mathrm{~h}$ fast.

A precipitation method with phosphotungstic acid- $\mathrm{MgCl}_{2}$ using Boehringer reagent kit (ref. 400971) was performed directly on serum to obtain HDL according to the method described by Draeger \& Wahlefeld (21).

Triglycerides, cholesterol, and phospholipids were determined in total serum and cholesterol and phospholipids in HDL using enzymatic techniques $(22-24)$ performed on a centrifugal analyser (Cobas-Bio Roche, France). Triglycerides were analysed using a Boehringer kit (test combination TG, ref. 24052), cholesterol using a Biotrol kit (Biopack cholesterol enzymatic color, ref. A01370), and phospholipids using a Wako kit (Pl-B test, ref. 279 54009). Serum apolipoprotein A was determined by laser nephelometry (Behring lab, Paris, France) on the HDLsupernatant, using a commercial anti $\mathrm{HDL}_{3}$ antibody (ref. OSIL 04/05, Behring). Apolipoprotein B was directly determined on the total serum after a dilution with detergent buffer, by laser nephelometry using a commercial anti apolipoprotein B antibody (ref. OSAN 04/05, Behring). Both apolipoprotein $A$ and apolipoprotein $B$ determinations using the laser nephelometric quantitation method were performed according to the recommendations of the manufacturer $(25,26)$.

\section{Expression of results and statistical analysis}

Based on previously published results from determinations in serum, we have defined the following so-called cardiovascular risk factors:

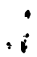


R1 as the ratio between the HDL-cholesterol and (total cholesterol minus HDL-cholesterol);

R2 as the ratio between HDL-phospholipids and (total phospholipids minus HDL-phospholipids);

$\mathrm{R} 3$ as the ratio between apolipoprotein $\mathrm{A}$ and apolipoprotein B.

All individual results were processed by computer and the means \pm SEM of each parameter calculated for each group of patients after two turns of truncation (mean $\pm 2 S D$ each time), thereby eliminating the highest and/or lowest values which would introduce a bias in the results and render the mean values unrepresentative of the group. The test of Kolmogorov \& Smirnov was applied to verify that the distribution of values in the groups of subjects was not significantly different from a Gaussian distribution. Thus, means of two groups were compared by Student's t test. For the group of uraemic undialysed patients and that of haemodialysed patients, the control group was composed of the 22 control patients who had a comparable mean age and sex ratio. For the group of renal transplant patients, the control group was composed of the 82 subjects who had a comparable age and sex ratio.

\section{Results}

Lipid anomalies associated with chronic renal failure

Table 2 shows that uraemic subjects, with or without haemodialysis, had increased serum triglycerides compared with control subjects, and normal serum total cholesterol and phospholipids. The mean serum concentration of apolipoprotein B was significantly decreased in haemodialysed patients as compared to control subjects, while that of uraemic undialysed patients was normal.

The analysis of the composition of HDL indicated that cholesterol content, phospholipids content and apolipoprotein A content were all decreased in both groups of uraemic patients. In fact, from these three determinations it was possible to demonstrate that the HDL of uraemic undialysed patients were decreased, because the ratios between protein and lipid components of this lipoprotein type were similar for these patients and for healthy controls. By contrast in haemodialysed patients only the ratio between apolipoprotein A and HDL-phospholipids was similar to that of control subjects, while both other ratios (HDL-cholesterol/HDL-phospholipids and apolipoprotein A/HDL-cholesterol) were significantly altered compared with that of normal subjects.

The cardiovascular risk factors were different according to whether they were established in terms of cholesterol, phospholipids or apolipoprotein. In uraemic undialysed patients all 3 ratios R1, R2, and R3 were significantly decreased by comparison with controls. In haemodialysed patients, R1 and R2 ratios were also significantly decreased compared with those of control subjects, whereas the $\mathrm{R} 3$ ratio (apolipoprotein A/apolipoprotein B) was comparable.

Tab. 2. Serum lipid parameters in control, haemodialysed and undialysed uraemic subjects (mean \pm SEM)

\begin{tabular}{|c|c|c|c|c|c|c|c|c|}
\hline & $\begin{array}{l}\text { Control } \\
\text { subjects }\end{array}$ & $\mathrm{n}$ & $\begin{array}{l}\text { Haemo- } \\
\text { dialysed } \\
\text { subjects }\end{array}$ & & $\mathrm{n}$ & $\begin{array}{l}\text { Uraemic } \\
\text { un- } \\
\text { dialysed } \\
\text { subjects }\end{array}$ & & $\mathrm{n}$ \\
\hline Total triglycerides (mmol/l) & $1.01 \pm 0.09$ & 22 & $1.83 \pm 0.09$ & c & 80 & $1.65 \pm 0.09$ & c & 53 \\
\hline Total cholesterol $(\mathrm{mmol} / \mathrm{l})$ & $5.27 \pm 0.24$ & 22 & $4.76 \pm 0.13$ & & 81 & $5.37 \pm 0.15$ & & 56 \\
\hline HDL-cholesterol (mmol/l) & $1.22 \pm 0.08$ & 22 & $0.82 \pm 0.02$ & c & 82 & $0.84 \pm 0.03$ & c & 58 \\
\hline $\mathrm{R} 1$ & $0.33 \pm 0.04$ & 22 & $0.20 \pm 0.01$ & c & 78 & $0.18 \pm 0.01$ & c & 55 \\
\hline Total phospholipids (mmol/l) & $3.09 \pm 0.10$ & 22 & $3.09 \pm 0.06$ & & 78 & $3.21 \pm 0.07$ & & 52 \\
\hline HDL=phospholipids (mmol/l) & $1.53 \pm 0.07$ & 22 & $1.18 \pm 0.02$ & c & 75 & $1.15 \pm 0.04$ & c & 54 \\
\hline $\mathrm{R} 2$ & $1.10 \pm 0.12$ & 22 & $0.61 \pm 0.02$ & c & 74 & $0.54 \pm 0.02$ & c & 50 \\
\hline Apolipoprotẹin A (g/l) & $2.06 \pm 0.07$ & 22 & $1.82 \pm 0.05$ & b & 79 & $1.72 \pm 0.04$ & c & 51 \\
\hline Apolipoprotein $\mathrm{B}(\mathrm{g} / \mathrm{l})$ & $1.06 \pm 0.05$ & 22 & $0.84 \pm 0.03$ & c & 79 & $0.99 \pm 0.04$ & & 54 \\
\hline $\mathrm{R} 3$ & $1.94 \pm 0.11$ & 22 & $2.13 \pm 0.07$ & & 79 & $1.67 \pm 0.06$ & a & 52 \\
\hline HDL-cholesterol/HDL-phospholipids & $0.78 \pm 0.03$ & 22 & $0.67 \pm 0.01$ & c & 76 & $0.75 \pm 0.02$ & & 54 \\
\hline Apolipoprotein A/HDL-cholesterol & $1.82 \pm 0.09$ & 22 & $2.26 \pm 0.06$ & c & 79 & $1.98 \pm 0.05$ & & 50 \\
\hline Apolipoprotein A/HDL-phospholipids & $1.39 \pm 0.05$ & 23 & $1.50 \pm 0.03$ & & 81 & $1.48 \pm 0.03$ & & 53 \\
\hline
\end{tabular}

The comparisons were performed using Student's $t$ test between haemodialysed subjects or uraemic undialysed subjects and control subjects. $a, b, c$, indicate $p<0.05, p<0.01$, and $p<0.001$, respectively.
R1 $=\frac{\text { HDL-cholesterol }}{\text { total cholesterol }- \text { HDL-cholesterol }}$
R2 $=\frac{\text { HDL-phospholipids }}{\text { total phospholipids - HDL-phospholipids }}$
R3 $=\frac{\text { apolipoprotein } A}{\text { apolipoprotein B }}$ 


\section{Lipid anomalies after kidney transplanta-} tion

Table 3 shows a significant increase in serum triglycerides, total cholesterol, phospholipids and apolipoprotein B concentrations in renal transplant patients compared with control subjects. Mean serum HDLcholesterol and HDL-phospholipids were normal while the mean apolipoprotein A concentration was significantly decreased in renal transplant patients compared with control subjects.

All three cardiovascular risk factors were significantly decreased in these patients compared with control subjects. The apolipoprotein A/HDL-cholesterol and apolipoprotein $\mathrm{A} / \mathrm{HDL}$-phospholipids ratios were similar in patients and controls, but the HDL-cholesterol/HDL-phospholipids ratios were slightly and significantly different.
Factors associated with lipid anomalies in uraemic patients

Table 4 shows that uraemic patients with a serum creatinine concentration $>400 \mu \mathrm{mol} / 1$ had lipid anomalies that were more marked than in uraemic patients with a serum creatinine epncentration $\leqslant 400$ $\mu \mathrm{mol} / \mathrm{l}$ (i. e., more marked degree of hypertriglyceridaemia, decrease of HDL-cholesterol, HDL-phospholipids and apolipoprotein $\mathrm{A}$ and decrease of $\mathrm{R} 1, \mathrm{R} 2$, and R3).

No relation could be established between any lipid parameter and the duration of dialysis in haemodialysed patients.

Tab. 3. Serum lipid parameters in control and renal transplant subjects (means \pm SEM). R1, R2 and R3 see table 2 .

\begin{tabular}{|c|c|c|c|c|c|}
\hline & Control subjects & $\mathfrak{n}$ & \multicolumn{2}{|c|}{$\begin{array}{l}\text { Renal } \\
\text { transplant subjects }\end{array}$} & $\mathbf{n}$ \\
\hline Total triglycerides $(\mathrm{mmol} / \mathrm{l})$ & $0.75 \pm 0.03$ & 71 & $1.07 \pm 0.08$ & c & 20 \\
\hline Total cholesterol (mmol/l) & $4.65 \pm 0.09$ & 75 & $5.80 \pm 0.20$ & c & 21 \\
\hline HDL-cholesterol (mmol/l) & $1.23 \pm 0.03$ & 77 & $1.30 \pm 0.09$ & & 22 \\
\hline R1 & $0.34 \pm 0.01$ & 74 & $0.28 \pm 0.02$ & $b$ & 20 \\
\hline Total phospholipids (inmol/l) & $2.87 \pm 0.05$ & 79 & $3.20 \pm 0.08$ & c & 20 \\
\hline HDL-phospholipids (mmol/l) & $1.48 \pm 0.03$ & 79 & $1.44 \pm 0.06$ & & 21 \\
\hline R2 & $1.09 \pm 0.04$ & 74 & $0.90 \pm 0.05$ & c & 21 \\
\hline Apolipoprotein A (g/l) & $2.13 \pm 0.03$ & 75 & $1.94 \pm 0.07$ & $\mathbf{a}$ & 19 \\
\hline Apolipoprotein B (g/l) & $0.87 \pm 0.02$ & 74 & $1.10 \pm 0.05$ & c & 19 \\
\hline R3 & $2.42 \pm 0.07$ & 75 & $1.90 \pm 0.10$ & c & 20 \\
\hline HDL-cholesterol/HDL-phospholipids & $0.84 \pm 0.01$ & 75 & $0.89 \pm 0.03$ & a & 20 \\
\hline Apolipoprotein A/HDL-cholesterol & $1.69 \pm 0.03$ & 71 & $1.60 \pm 0.10$ & & 19 \\
\hline Apolipoprotein A/HDL-phospholipids & $1.43 \pm 0.02$ & 73 & $1.38 \pm 0.06$ & & 20. \\
\hline
\end{tabular}

The comparisons were performed using Student's $t$ test between renal transplant subjects and control subjects. a, b, and c indicate $\mathrm{p}<0.05, \mathrm{p}<0.01$, and $\mathrm{p}<0.001$, respectively. R1, R2 and R3 see table 2 .

Tab. 4. Influence of degree of chronic renal failure on serum lipid parameters (mean $\pm S E M$ ). R1, R2 and R3 see table 2.

\begin{tabular}{|c|c|c|c|c|c|c|}
\hline & $\begin{array}{l}\text { Patients } \\
\text { with creatinine } \\
\leqslant 400 \mu \mathrm{mol} / \mathrm{l}\end{array}$ & $\mathbf{n}$ & & $\begin{array}{l}\text { Patients } \\
\text { with creatinine } \\
>400 \mu \mathrm{mol} / \mathrm{l}\end{array}$ & $\mathrm{n}$ & $\dot{\mathrm{p}}$ values \\
\hline $\begin{array}{l}\text { Total triglycerides (mmol/l) } \\
\text { Total cholesterol (mmol/l) } \\
\text { HDL-cholesterol (mmol/l) } \\
\text { R1 } \\
\text { Total phospholipids (mmol/l) } \\
\text { HDL-phospholipids (mmol/l) } \\
\text { R2 } \\
\text { Apolipoprotein A (g/l) } \\
\text { Apolipoprotein B (g/l) } \\
\text { R3 }\end{array}$ & $\begin{array}{l}1.42 \pm 0.12 \\
5.25 \pm 0.19 \\
0.94 \pm 0.04 \\
0.22 \pm 0.02 \\
3.22 \pm 0.08 \\
1.31 \pm 0.05 \\
0.64 \pm 0.04 \\
1.89 \pm 0.06 \\
0.96 \pm 0.05 \\
1.88 \pm 0.12\end{array}$ & $\begin{array}{l}23 \\
23 \\
24 \\
25 \\
21 \\
25 \\
23 \\
24 \\
22 \\
24\end{array}$ & • & $\begin{array}{l}1.94 \pm 0.14 \\
5.29 \pm 0.23 \\
0.75 \pm 0.03 \\
0.17 \pm 0.01 \\
3.17 \pm 0.10 \\
1.03 \pm 0.04 \\
0.51 \pm 0.02 \\
1.52 \pm 0.05 \\
1.01 \pm 0.05 \\
1.56 \pm 0.07\end{array}$ & $\begin{array}{l}32 \\
35 \\
33 \\
32 \\
30 \\
29 \\
29 \\
29 \\
32 \\
29\end{array}$ & $\begin{array}{l}<0.01 \\
\text { NS } \\
<0.001 \\
<0.01 \\
\text { NS } \\
<0.001 \\
<0.01 \\
<0.001 \\
\text { NS } \\
<0.02\end{array}$ \\
\hline
\end{tabular}




\section{Discussion}

The present study confirms previously well-known lipid anomalies in uraemic patients treated or untreated by intermittent haemodialysis, i. e., hypertriglyceridaemia, a decrease of serum HDL-cholesterol and an increase of the so-called cardiovascular risk factors $(13,15,16,18-20,27-38)$. In addition, we have demonstrated that lipid anomalies were more marked in uraemic patients with more advanced renal failure than in those with moderate renal insufficiency. In the literature no relation was established between any of the serum lipid parameters and the degree of renal insufficiency (35). In haemodialysed patients, we found no correlation between the duration of haemodialysis and the magnitude of serum lipid anomalies, a finding that agrees with another earlier report (36).

Serum HDL-phospholipids have already been found to be decreased in uraemic patients treated or untreated by haemodialysis $(32,37)$, whereas apolipoprotein $A$ has been reported to be normal $(13,16,19)$, or decreased $(15,17,18)$ in haemodialysed patients. In the present study, a significant decrease in serum HDL-phospholipids and apolipoprotein A was observed in uraemic patients, with or without haemodialysis.

Hypertriglyceridaemia and hypercholesterolaemia following renal transplantation have already been reported $(20,27,28,30,34,39,40)$ and were also observed in the present study. The concentration of serum HDL-cholesterol was reported to be normal $(14,16,27,34,40)$, decreased $(28,30)$, or even increaśed $(19,20)$. Serum apolipoprotein A concentration was reported to be normal (16) or increased $(14,19)$. In our renal transplant patients, we have observed a normal serum concentration of HDLcholesterol and HDL-phospholipids and a slightly but significantly decreased concentration of apolipoprotein A.

The so-called cardiovascular risk factors were determined using either the ratio of cholesterol contained in HDL to that in (LDL + VLDL) or the ratio of apolipoprotein A to apolipoprotein B. Several studies indicated that the two modes of evaluation were not strictly superimposable, at least in the patient population with a history of myocardial infarct (12, $41-43)$. In the present uraemic patients as well as renal transplant patients, these ratios using cholesterol or phospholipids were decreased. However, the decrease of the apolipoprotein A/apolipoprotein B ratio in uraemic and renal transplant patients lipoprotein did not parallel the decrease of the other two ratios. Thus, the ratios of cholesterol, phospholipids and apolipoprotein A contents were not superim- posable in the three patient groups. This suggests that relative changes of the lipid and protein structure within the HDL of these patients must have occurred. It has been reported by others that the decrease in HDL-cholesterol paralleled the decrease in HDLphospholipids in haemodialysed patients (32) while the ratio between HDL-cholesterol and apolipoprotein A was decreased in these patients $(16,19)$, in contrast to the close correlation between apolipoprotein $\mathrm{A}$ and HDL-cholesterol concentrations in controls. The correlation coefficient between apolipoprotein A and HDL-cholesterol was 0.701 in control subjects, 0.607 in uraemic undialysed and 0.432 in haemodialysed patients. Brunzell et al. (13) reported a similarly low correlation coefficient $(0.34)$ between apolipoprotein A-I and HDL-cholesterol in a patient population receiving dialysis treatment. Uraemia could therefore interfere with the binding of cholesterol to its apoproteins, analogous to the reduction of drug or metabolite binding to plasma proteins. This phenomenon could be independent of the HDL enrichment with triglycerides as suggested by Rapoport et al. (18) and could be a primary phenomenon. For renal transplant patients the HDL-cholesterol/ apolipoprotein A ratio has been reported to be normal $(16,19)$ or decreased $(14)$. In our study, this ratio, as well as the HDL-cholesterol/HDL-phospholipids and apolipoprotein A/HDL-phospholipids ratios, were normal for renal transplant patients.

If one considers that the cholesterol content of HDL reflects the protein's ability to accept cholesterol and that this is the limiting factor for cholesterol uptake from tissues, then the results of our study would be in line with the hypothesis that HDL from uraemic patients take up less cholesterol from tissues than HDL from normal healthy subjects.

In conclusion it seems difficult at present to decide whether the apolipoprotein A/apolipoprotein B ratio is a better marker in terms of cardiovascular risk factors than the ratio of HDL-cholesterol to total cholesterol minus HDL-cholesterol for uraemic and renal transplant patients. In our opinion, these two determinations should rather be treated as complementary to one another, in order to better understand the anomalies of the HDL composition in these patients and their probable role in the pathogenesis of their accelerated cardiovascular disease. A similar suggestion has already been made for non uraemic patients with coronary artery disease (43).

\section{Acknowledgements}

The authors would like to thank Ms Dany Masson and Isabelle Gadbi for valuable secretarial help, and Mr Gilles Dumont for statistical analysis. 


\section{References}

1. Lindner, A., Charra, B., Sherrard, D. J. \& Scribner, B. H. (1974) N. Engl. J. Med. 290, 697-701.

2. Lazarus, J. M., Lowrie, E. G., Hampers, C. L. \& Merrill, J. P. (1975) Kidney Int. 7, Suppl 2, S 167-175.

3. Jacobs, C., Brunner, F. P., Chantler, C., Donckerwolcke, R. A., Gurland, H. J., Hathway, R. A., Selwood, N. H. \& Wing, A. J. (1977) Proc. Eur. Dial. Transplant. Assoc. 14, 3-69.

4. Lowrie, E. G., Lazarus, J. M., Mocelin, A. J., Bailey, G. L., Hampers, C. L., Wilson, R. E. \& Merril, J.P. (1973) N. Engl. J. Med. 288, 863-867.

5. Ibels, L. S., Stewart, J. H., Hahony, J. F., Neale, F. C. \& Sheil, A. G. R. (1977) Quart. J. Med. 46, 197-214.

6. Heuck, C. C. \& Ritz, E. (1980) Nephron 25, 1-7.

7. Chan, M. K., Varghese, Z. \& Moorhead, J. F. (1981) Kidney Int. 19, 625-637.

8. Gordon, T., Castelli, W. P., Hjortland, M. C., Kannel, W. B. \& Dawber, T. R. (1977) Am. J. Med. 62, 707-714.

9. Miller, N. E., Forde, O. H., Thelle, S. D. \& Mjos, O. D. (1977) Lancet $l, 965-968$

10. Miller, G. J. (1980) Ann. Rev. Med. 31, 97-108.

11. Tutor, J. C., Paz, J. M., Areses, J. \& Garcia, F. (1981) Biometrica VI 2, 65-69.

12. Maciejko, J. J., Holmes, D. R., Kottke, B. A., Zinsmeister, A. R., Dinh, D. M. \& Mao, S. J. T. (1983) N. Engl. J. Med. $309,385-389$.

13. Brunzell, J. D., Albers, J. J., Haas, L. B., Goldberg, A. P., Agadoa, L. \& Sherrard, D. J. (1977) Metabolism 26, 903-910.

14. Jung, K., Neumann, R., Scholz, D. \& Nugel, E. (1982) Clin. Nephrol. 17, $191-194$.

15. Ron, D., Oren, I., Aviram, M., Better, O. S. \& Brook, J. G. (1983) Atherosclerosis 46, 67-75.

16. Savdie, E., Gibson, J. C., Stewart, J. H. \& Simons, L. A. (1979) Brit. Med. J. 1, 928-930.

17. Staprans, I., Felts, J. M. \& Zacherle, B. (1979) Clin. Chim. Acta 93, 135-143.

18. Rapoport, J., Aviram, M., Chaimovitz, C. \& Brook, J. G. (1978) N. Engl. J. Med. 229, 1326-1329.

19. Rubies-Prat, J., Romero, R., Chacon, P., Masdeu, S., Grino, J. \& Caralps, A. (1983) Nephron 35, 171-174.

20. Kobayashi, N., Okubo, M., Marumo, F., Uchida, H., Endo, T. \& Nakamura, H. (1983) Nephron 35, 237-240.

21. Draeger, B. \& Wahlefeld, A. W. (1980) In: Lipoproteins and coronary heart disease (Greten, H., Lang, P. D. \& Schettler, G., eds.) New-York, Baden-Baden, Cologne, Witzstrock Publishing House, pp. 38-42.
22. Eggstein, M. \& Kreutz, F. H. (1966) Klin. Wochenschr. 44, 262-267.

23. Röschlau, P., Bernt, E. \& Gruber, W. (1974) J. Clin. Chem. Clin. Biochem. 12, 403-407.

24. Takayama, M., Itoh, S., Nagasaki, T. \& Tanimizu, I. (1977) Clin. Chim. Acta 79, 93 -98 .

25. Becker, W., Shafer, W. \& Ziegenbein! W. (1980) La Ricerca Clin. Lab. 10, 203-212.

26. Munscher, G., Metzmann, E. \& Ziegenbein, W. (1982) La Ricerca Clin. Lab. 12, 143-154.

27. Ibels, L. S., Simons, L. A., King, J. O., Williams, P. F., Neale, F. C. \& Stewart, J. H. (1975) Quart. J. Med., New series, $X L I V n^{\circ} 176,601-614$.

28. Bagdade, J., Casaretto, A. \& Albers, J. (1976) J. Lab. Clin. Med. 87, 37-48.

29. Daubresse, J. C., Lerson, G., Plompteux, G., Rorive, G., Luyckx, A. S. \& Lefebvre, P. J. (1976) Eur. J. Clin. Invest. 6, 159-166.

30. Bagdade, J. D. \& Albers, J. J. (1977) N. Engl. J. Med. 296, $1436-1439$.

31. Attman, P. O. \& Gustafson, A. (1979) Eur. J. Clin. Invest. 9, 285-291.

32. Somer, J. B., Aitken, J. M., Abbott, L. K., Charlesworth J. A., Mac Donald, G. \& Blacket, R. B. (1979) Atherosclerosis $34,353-364$

33. Perez, G. O., Hsia, S. L., Christakis, G. \& Burr, J. (1980) Horm. Metab. Res. 12, $449-454$.

34. Nicholls, S. J., Cumming, A. M., Catto, G. R. D., Edward, N. \& Engeset, J. (1981) Quart. J. Med., New series, $L n^{\circ}$ $198,149-160$.

35. Norbeck, H. E. (1981) Acta Med. Scand. S 649, 1-49.

36. Chan, M. K., Varghese, Z., Persaud, J. W., Baillod, R. A. \& Moorhead, J. F. (1982) Clin. Nephrol. 17, 183-190.

37. Chapkin, R. S., Haberstroh, B., Liu, T. \& Holub, B. J. (1983) J. Lab. Clin. Med. 101, 726-735.

38. Hahn, R., Oette, K., Mondorf, H., Finke, K. \& Sieberth, H. G. (1983) Atherosclerosis 48, 279-288.

39. Ibels, L. S., Reardon, M. F. \& Nestel, P. J. (1976) J. Lab. Clin. Med. 87, 648-658.

40. Somer, J. B., Abbott, L. K., Aitken, J. M. \& Elliott, C. -(1979) Clin. Chim. Acta 97, 123-134.

41. Avogaro, P., Bittolo Bon, G.. Cazzolato, G. \& Quinci, G. B. (1979) Lancet $I, 901-903$.

42. Brook, J. G., Aviram, M., Viener, A., Shilansky, E. \& Markiewicz, W. (1982) Circulation 66, 923-926.

43. Noma, A., Yokosuka, T. \& Kitamura, K. (1983) Atherosclerosis 49, 1-7.

\section{Dr. B. Lacour}

Laboratoire de Biochimie A

Hôpital Necker

149 rue de Sèvres

F-75015 Paris Cédex 15 